\title{
Seasonal shifts in the life cycle of the ponto-caspian invader Limnomysis benedeni (Crustacea: Mysida): a physiological adaptation?
}

\author{
Almut J. Hanselmann • René Gergs • \\ Karl-Otto Rothhaupt
}

\begin{abstract}
The mysid Limnomysis benedeni, one of the most important ponto-caspian invaders, was found in Lake Constance (southern Germany) in 2006. As part of larger studies to evaluate the effects of $L$. benedeni on the ecosystem, we studied its life-cycle strategies over an entire seasonal cycle in intervals of 3-5 weeks, addressing factors (predation, temperature) which we expected to be most important triggers of the observed changes. The size class distribution and the reproductive pattern indicated that the life cycle of L. benedeni changes seasonally. During winter (November to March), the mysid invested energy in growth and delayed reproduction until April, when the population was dominated by adults. In summer (June to September), the adults reproduced at a smaller body size and the population was disproportionately dominated by juveniles. In a mesocosm experiment that excluded fish predators, the mysids followed the same seasonal patterns of growth and energy investment as in the field population, but the size class distribution
\end{abstract}

\section{Handling editor: B. Oertli}

A. J. Hanselmann $(\bowtie) \cdot$ K.-O. Rothhaupt Limnological Institute, University of Konstanz, Mainaustraße 252, 78464 Constance, Germany e-mail: almut.hanselmann@gmx.de

R. Gergs

Institute for Environmental Sciences, University of Koblenz-Landau, Fortstraße 7, 76829 Landau, Germany differed. Even in summer, the population in the mesocosm was dominated by adults. Stomach analyses of fish showed that $L$. benedeni is preyed upon by juvenile Perca fluviatilis, which fed size selectively on larger mysids. In conclusion, our results suggest predation was the reason for the dominance of juveniles and the observed size class distribution in summer. In contrast, the smaller adults in summer were most likely a physiological adaptation, perhaps evolved to avoid predation or as a reaction on metabolic losses at higher temperatures.

Keywords Invasive species - Life history - Body size . Littoral zone Fish predation - Temperature

\section{Introduction}

The life cycle of a species summarizes its various energy investments and presumably optimizes fitness. An animal has a limited amount of energy, and the allocation of this energy to growth or reproduction leads to different life-cycle strategies (Stearns, 1989). Local and temporal variations in life cycles are influenced by differing or changing environmental conditions, in terms of both abiotic factors such as temperature and water chemistry, and biotic factors such as food availability, competition, and predation. To reliably describe a community and understand the functioning of aquatic ecosystems in general, it is necessary to start with gaining knowledge about the 
life cycle of the respective species. The sum of these findings allows you then, for example, to estimate the impact of invasions by alien species. Life cycles vary in timing of reproduction and maturation, rate of growth, and clutch size among others. Since these life-cycle characteristics can vary considerably within the range of a species, investigating field patterns of local population structure and life cycle is essential for describing the species (for a summary, see Begon et al., 1998; Krebs, 2001).

The mysid Limnomysis benedeni Czerniavsky, 1882 is one of the most invasive mysids in Europe although little is known about the factors affecting its life cycle and life-cycle traits. It has been characterized as necto-benthic (Porter et al., 2008) and phytolithophilic (Dediu, 1966) with a preference for smaller particles (Gergs et al., 2008; Aßmann et al., 2009). This common invader originates in the brackish estuaries of the Black and Caspian Seas and has spread widely in Eastern and Central Europe since the early twentieth century; the large Rivers Danube and Rhine serving as invasion corridors (Bij De Vaate et al., 2002; Audzijonyte et al., 2009; Wittmann \& Ariani, 2009).

The mysid was found for the first time in the eastern part of Lake Constance in 2006, near the influx of the river Rhine in Austria (Fritz et al., 2006). Mysids can be a good food source for fish (Mauchline, 1982; Chigbu \& Sibley, 1998; Lindén et al., 2003), and like other mysids, L. benedeni was introduced to lakes in Northern and Eastern Europe in the early 20th century (Bacescu, 1954; Wonyárovich, 1955; Lasenby et al., 1986) to enhance fish production, although the expected benefit was not always realized (Langeland et al., 1991). Nevertheless, L. benedeni is an important food source for the two Sander species in Lake Balaton, for instance (Specziár, 2005).

The particular life cycle of different species within the crustacean order Mysida vary inter alia with climate regime (Wittmann, 1984). Differences between species may be substantial, particularly in brood size (1-350 eggs/brood), generation time (a few weeks to 2 years), embryonic development time (a few days to several months) and pattern of reproduction (in cohorts or continuous) (e.g., Mauchline, 1980; Wittmann, 1984; Johnston et al., 1997). In temperate areas, such as in Central and Eastern Europe, mysids usually reproduce in the warmer season, with two or more broods per reproduction period, and greater numbers of larvae per brood in spring (Mauchline, 1973; Mauchline, 1980; Wittmann, 1984). This might also be true for L. benedeni, as indicated by initial findings in Lake Constance in spring and summer 2007 (Gergs et al., 2008), in the River Rhine in both the Netherlands (Kelleher et al., 1999) and France (Wittmann \& Ariani, 2000), and in the Danube basin (Bacescu, 1954). However, in all these studies, only one or two single samples were analysed, and sampling was not consistent over an entire seasonal cycle. Since no complete seasonal data set on the population is available, the year-round life cycle of $L$. benedeni is still unknown. Here, we combined field samplings and mesocosm experiments to obtain data on the life cycle of $L$. benedeni in Lake Constance, covering the entire seasonal cycle at a high temporal resolution. We also evaluated information about the factors that we expected could be responsible for the patterns observed (predation and temperature).

\section{Methods}

\section{Field sampling}

We chose as the study site the location where L. benedeni was first found in Lake Constance in summer 2006 (Fritz et al., 2006) because we expected the most stable population there. The study ran from October 2007 until November 2008, with sampling intervals of 3-5 weeks. Because of the higher water temperature in summer, we sampled more frequently then. The substratum at the sampling site is very homogeneous with stones and rocks along ca. $900 \mathrm{~m}$ shoreline. We collected $L$. benedeni at about $0.5 \mathrm{~m}$ depth by kick sampling (mesh size $200 \mu \mathrm{m}$ ) and measured body size, brood size and stage composition (juvenile, female ore male). The mysids were immediately fixed in $96 \%$ ethanol in the field. 5 additional breeding females were caught on 9 July 2008 and 9 October 2008 to be able to calculate an average for the brood size.

Water temperature was recorded on every sampling date from 8 October 2007 to 6 November 2008 (MultiLine F/SET-3, WTW, Weilheim, Germany). The presence and estimated age of any perch in spring and summer was verified by snorkeling. For 
this, an area of $15 \times 5 \mathrm{~m}$ was observed and schools of perch were assigned as present or not.

\section{Mesocosm}

The outdoor mesocosm is located in Konstanz, close to the Limnological Institute. It consists of a concrete basin $(1 \times 1 \mathrm{~m}, 60 \mathrm{~cm}$ water depth, $600 \mathrm{l})$ with a flow-through of filtered $(200 \mu \mathrm{m})$ lake water $(\sim 1.5 \mathrm{l} / \mathrm{min})$. Stones from the nearby littoral zone of the same size as found at our field site $(4-10 \mathrm{~cm})$ served as a substratum. We collected the stones in May 2008 and cleaned them with a hard water jet to remove possible predators. On 29 May 2008, we added to the mesocosm $500 \mathrm{~L}$. benedeni originating from our field sampling site in Austria. This number is comparable to field abundances (A. J. Hanselmann, unpublished data). On 4 August and 10 October 2008, we collected the mysids by kick sampling, and measured body size and stage composition (see above). Algae and biofilm were seen on the substrate every time and the constant water flow from the lake (lake seston $<200 \mu \mathrm{m}$ ) provided additional food. Supported by a quick check of the gut fullness of some mysids (for methods see Gergs et al., 2008), we concluded that no food limitation or crowding occurred in the mesocosm.

\section{Laboratory analyses}

We measured the body size of the sampled mysids using a measurement program developed by the electronic facilities of the University of Konstanz (G. Heine). Individuals were photographed under a stereomicroscope with an attached fire-wire camera (The Imaging Source, Bremen, Germany) connected to a computer, and directly measured. The body size was the mean of three measurements from the top of the rostrum to the end of the telson, excluding spines (e.g. Schleuter et al., 1998). The animals were arranged according to length classes (class width $0.5 \mathrm{~mm}$ ). We distinguished three groups in the population: juveniles, adult females, and adult males. Juveniles and adults were separated not by size but rather by indicative morphological features. Adult males were recognized by the remarkably longer 4th pleopod. Females carrying offspring were recognized by their marsupium (brood pouch), and females without offspring were recognized by the oostegites (lamellae at the ventral end of the thorax, which form the brood pouch) or the normal 4th pleopod (Mauchline, 1980). We also counted the brood size of the females. The ash-free dry mass (AFDM) of nonpreserved eggs was determined by drying at $105^{\circ} \mathrm{C}$ for $24 \mathrm{~h}$, followed by combustion at $550^{\circ} \mathrm{C}$ for $8 \mathrm{~h}$. AFDM of the females was calculated with the equation from Gergs et al. (2008).

\section{Analysis of perch stomachs}

To investigate the predation of perch (Perca fluviatilis L.) on L. benedeni in the field, we collected young $0+$ perch at our sampling site with a beach seine (mesh width $5 \mathrm{~mm}$ ) on 29 July 2009. The fish were stored on ice for transportation (max. $2 \mathrm{~h}$ ) and the stomach was removed in the laboratory immediately and preserved in $96 \%$ ethanol. The wet weight of the fish and the total length was noted. By means of a stereomicroscope, the stomach contents were analyzed. It was noted if the stomachs contained $L$. benedeni and ingested $L$. benedeni were separated into two classes, juveniles $<5.0 \mathrm{~mm}$ and adults $>5.0 \mathrm{~mm}$. At the same date, we collected and measured L. benedeni as described above and classified them the same way as the animals in the stomachs.

\section{Statistical analyses}

All statistical analyses were made using $\mathrm{R}$ ( $\mathrm{R}$ Development Core Team, 2008). Before calculating any statistical test, we checked for homogenous variances.

In all calculated ANCOVAs, the body size was the dependent variable and the date the co-variable. To analyze the differences in the adult body size between the two generations (summer and winter), we calculated a two-way ANCOVA after transforming the data with $1 / x$. The independent variable was the generation. In addition, each temporal development of adult body size in winter and summer was calculated with a one-way ANCOVA including correlation coeffients. Differences between the length of males and females were determined with two-way ANCOVA; the independent variable was the sex. Seasonal characteristics were determined with oneway ANCOVAs including correlation coeffients for each sex. A $t$ test was used to compare brood sizes in 
spring and summer: to accordance of the mean body size in the mesocosm and the field was tested with a Mann-Whitney $U$ test owing to significant variances. The Mann-Whitney $U$ test was also used to examine the differences between the proportion of body mass and egg mass on the total female biomass of the winter and summer females. The proportions of large L. benedeni in the field and in the fish stomachs were compared using the $z$ ratio for the significance of the difference between two independent proportions. To compare the mean size of the perch eaten small ore large mysids, a $t$ test was calculated.

\section{Results}

\section{Field observations}

The temperature at the sampling site at $0.5 \mathrm{~m}$ depth (Fig. 1) varied greatly over the year. The highest temperature $\left(22.9^{\circ} \mathrm{C}\right)$ was at the end of July, and the lowest temperature $\left(5.0^{\circ} \mathrm{C}\right)$ was in January and February. The weather on the sampling dates was always fair with calm waves, except for 9 March, 2008 when strong winds and waves prevailed. From July until September 2008, we found perch $(0+)$ in the littoral zone (Fig. 1). No other fish species was recognized. In July, the perch were smaller but more abundant than in September, when the largest perch were present.

Population characteristics in the field

The stage and size class composition of the L. benedeni population changed during the year (Fig. 2). In the winter half year, from November until the end of April, the mean body size of all individuals increased, and in late winter and spring, adults dominated (percent composition of adults in March $=96 \%$ ). The first juveniles were observed at the end of May (Fig. 2). After that the juveniles began to dominate. During summer, juveniles dominated the population, and the entire length distribution was skewed toward smaller individuals (percent composition of juveniles at the end of July $=92 \%$ ). Only few animals reached sexual maturity. In November, the adults dominated again (percent composition of adults $=76 \%$ ). The sex ratio in 24 April and 28 May is more in favor of females compared to the other samplings.

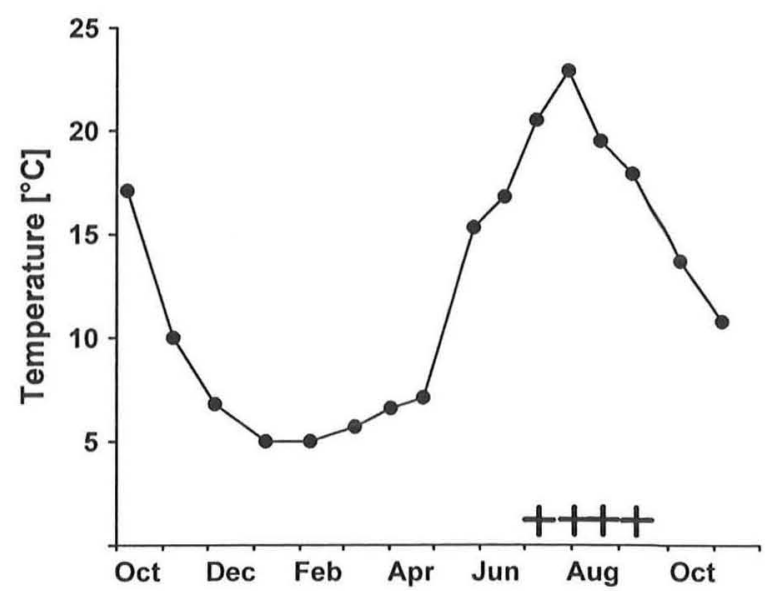

Fig. 1 Water temperature at $0.5 \mathrm{~m}$ depth (line with dots) and occurrence of juvenile Perca fluviatilis (+) at the sampling site in Austria. Lines between the sampled temperature values (dots) are interpolated

The body size of the three smallest juveniles showed little variation and did not vary between winter (1.65 $\pm 0.14 \mathrm{~mm}$ in May) and summer (1.72 \pm 0.14 $\mathrm{mm}$ ) generations. In contrast, adult body size varied markedly between the generations (Fig. 3; Table 1, date $\times$ generation: $P<0.001)$. In winter, the body size increased as the season advanced (Table 1, date: $P<0.001$, coef is positive). The mean body size in spring (24 April, 2008) was $9.0 \pm 0.1 \mathrm{~mm}$ (females $9.1 \pm 0.8 \mathrm{~mm}$, males $8.6 \pm 0.1 \mathrm{~mm}$ ). During summer, the adult mean length did not vary between the sampling dates (Table 1 , date: $P=0.176$ ). The mean body size was $6.1 \pm 0.2 \mathrm{~mm}$ (females $5.9 \pm 0.3 \mathrm{~mm}$, males $6.4 \pm 0.6 \mathrm{~mm})$. In autumn, the adults grew larger again. The maximum body size in summer (8.5 mm, observed in 18 June, 2008) was lower than the maximum body size in winter/spring $(11.4 \mathrm{~mm}$, observed in 24 April, 2008).

The size at maturity differed between spring (adults from winter half year) and summer (Fig. 4C). In the size class between 5.0 and $5.5 \mathrm{~mm}$ from October to April, 0-33\% of the animals were adult females or males; from May to September, all animals (100\%) of this size class were adults (Fig. 4C). For further calculations, we therefore defined as juveniles all animals $\leq 5.5 \mathrm{~mm}$ in body size during the winter period, and $\leq 5.0 \mathrm{~mm}$ during the summer period.

The proportion of egg-carrying females ( $\%$ of all adult females) changed with the season (Fig. 4A). No broods were found during winter until March. In April 


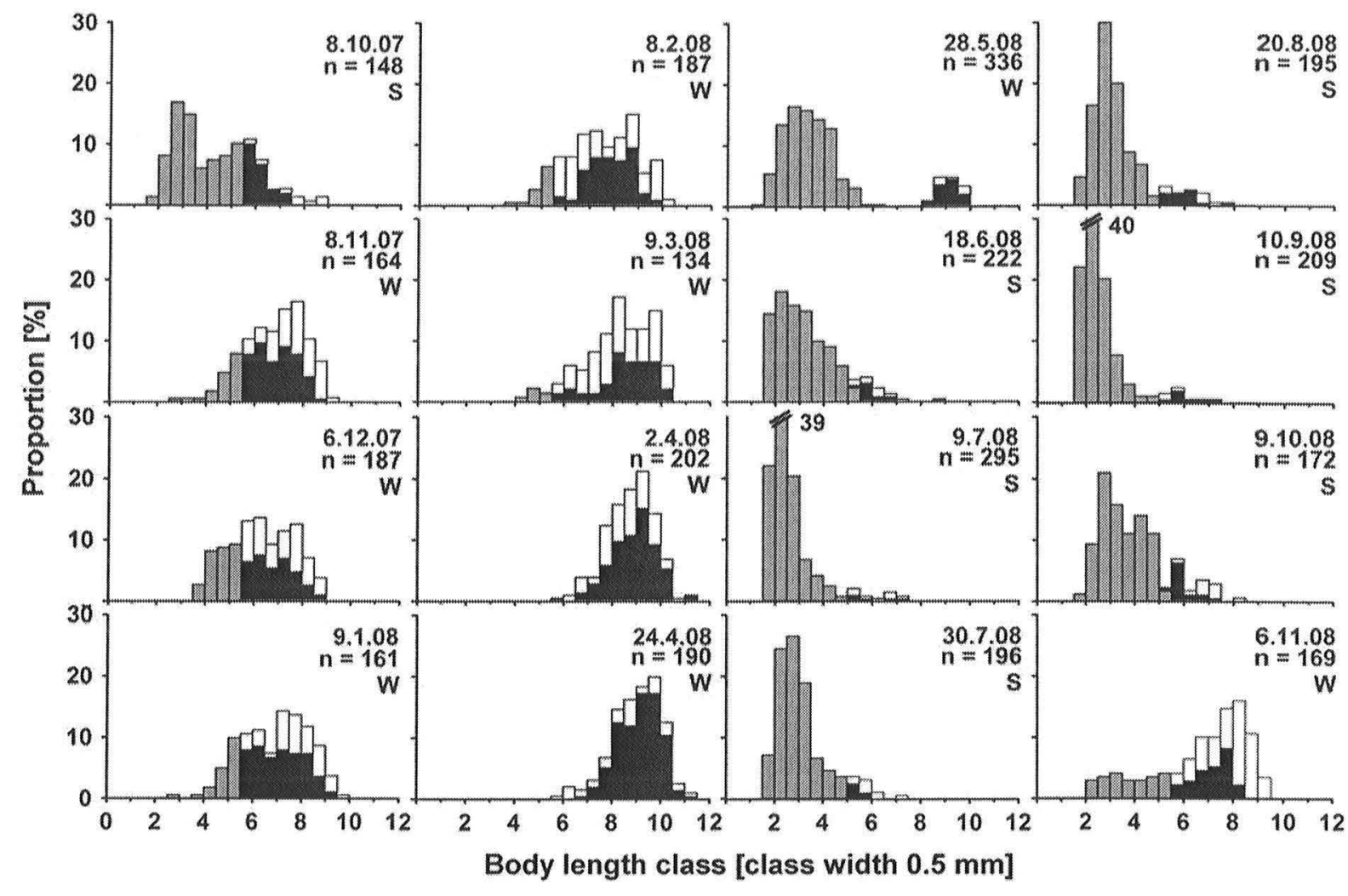

Fig. 2 Development of the body size of Limnomysis benedeni (measured from the apex to the end of the telson, see "Methods" section) from a qualitative subsample at $0.5 \mathrm{~m}$ depth over

and May, when the animals from winter were breeding, nearly all females were carrying a brood. The proportion decreased in June, was apparently zero in late July, and increased again in August. The very low sample sizes of adults in July may have made it difficult to detect any gravid females. Reproduction stopped in late October; the last breeding females were observed on 9 October 2008. The significant difference in brood size with season ( $t$ test, $P<0.001$ ) paralleled the difference in female mean length between summer and winter: spring females carried $20.5 \pm 1.1$ eggs/gravid female on average while summer females carried $6.9 \pm 0.9 \mathrm{eggs} /$ gravid female (Fig. 4A). The mean proportion of the eggs on the total biomass of the breeding females (Fig. 4B) was $23.6 \pm 5.8 \%$. No differences between the winter females $(22.8 \pm 1.4 \%)$ and the summer females $(24.3 \pm 6.8 \%)$ could be found ( $U$ test $P=0.548$ ).

The life-cycle characteristics of adult males and females differed in some respects (Fig. 3; Table 2). During winter, all adults increased in size (Table 2,
14 months; $n=$ number of measured individuals; gray bar juveniles, white bar males, black bar females; $W$ winter generation, $S$ summer generation (for definitions, see text)

date: $p<0.001$ each, coef is positive), but the females increased in size more than the males (Table 2, date $\times$ sex: $P<0.001)$ as indicated by correlation coefficients (Table 2). In summer, males and females again differed in body length (Table 2 , date $x$ sex: $P=0.011)$. The females did not increase in length (Table 2, date: $P=0.671$ ), whereas the males did (Table 2, date: $P=0.006$ ). This difference, however, arose only from the data of the last sampling of males in October 2008. The same ANCOVA calculated without this date was not significant (date $\times$ sex: $P=0.96$ ), so the mean length of the adults did not change during summer (Table 2).

\section{Mesocosm data}

The size structure of the mesocosm population differed from the size structure of the field population (Fig. 5), measured on the same dates. In contrast to the field population, no length class dominated clearly in the mesocosm population in August. The length 


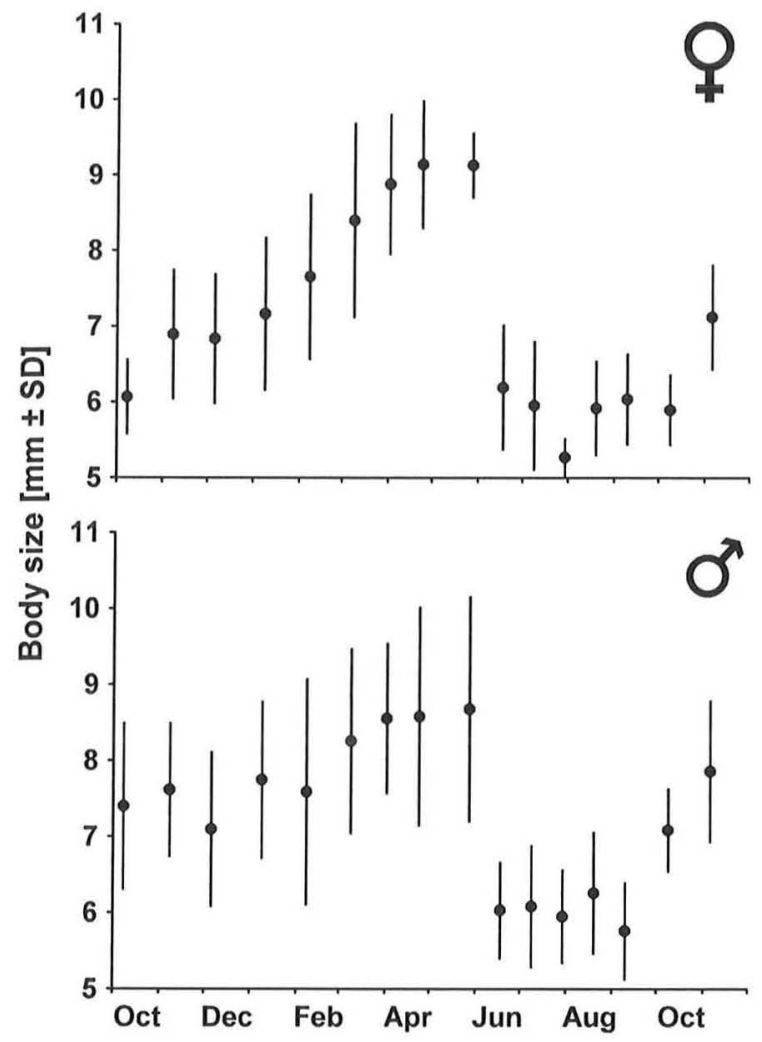

Fig. 3 Body size of adult Limnomysis benedeni (mean \pm SD) over the entire sampling period from 8 October 2007 to 6 November 2008. Refer to the text for an explanation of which mysids were counted as adult

classes were distributed in a bell-shaped manner (Fig. 5). In October, at the end of the reproduction period, most individuals were of adult size. However, the adult mean body size did not differ from the field data ( $U$ test, $P<0.001$ ). In the mesocosm, the body size on 4 August 2008 was $5.5 \pm 0.3 \mathrm{~mm}$ (males $5.5 \pm 0.4 \mathrm{~mm}$, females $5.4 \pm 0.3 \mathrm{~mm}$ ), and on 10
October 2008 it was $6.2 \pm 0.4 \mathrm{~mm}$ (males $6.4 \pm 0.3 \mathrm{~mm}$, females $6.1 \pm 0.3 \mathrm{~mm}$ ).

Stomach analysis of perch

The mean standard length of the perch captured with the beach seine was $6.1 \pm 0.5 \mathrm{~cm}$, the mean wet weight $2.4 \pm 0.6 \mathrm{~g}$. The population of $L$. benedeni at the same time showed an equal size distribution as in the year before (Fig. 2). In comparison with the available population of $L$. benedeni, the perch clearly preferred the larger mysids (Fig. 6). The proportion of large mysids in the field population was 0.0815 (15 individuals out of 184 in the sample). A total of 139 perch were caught. 118 of these fishes had mysids in their stomachs, indicating that $L$. benedeni was used as a food item by most fish (85\%). 38 fish had ingested only small mysids; 51 fish had ingested both small and large mysids; 29 fish had ingested only large mysids. These numbers show that large mysids were found disproportionally more frequent in the perch stomachs. Even a very conservative assessment, considering only the 29 perch that had exclusively ingested large mysids, indicates that this number is exceedingly high; the proportion of large L. benedeni in the fish stomachs was significantly higher than the proportion of large L. benedeni in the field sample ( $z$ ratio, $P<0.01$ ). No significant difference was found between the size of the fish fed on small or on large mysids ( $t$ test, $P=0.84$ ).

\section{Discussion}

During a 1-year period, the population of $L$. benedeni in Lake Constance underwent substantial changes in

Table 1 Changing of adult body length in winter and summer and differences between these generations, analyzed by one-way and two-way ANCOVAs

\begin{tabular}{|c|c|c|c|c|c|c|c|c|c|c|c|}
\hline & \multicolumn{3}{|c|}{ Two-way ANCOVA } & \multicolumn{4}{|c|}{ One-way ANCOVA } & \multicolumn{4}{|c|}{ One-way ANCOVA } \\
\hline & \multicolumn{3}{|c|}{ Winter/summer } & \multicolumn{4}{|l|}{ Winter } & \multicolumn{4}{|l|}{ Summer } \\
\hline & $P$ value & $\mathrm{df}$ & $F$ & $P$ value & coef & df & $F$ & $P$ value & coef & $\mathrm{df}$ & $F$ \\
\hline Date & $0.049782 *$ & 1 & 3.9 & $<0.001 * * *$ & 0.0122 & 1 & 497.6 & 0.176 & 0.0022 & 1 & 1.9 \\
\hline Generation & $<0.001 * * *$ & 1 & 979.5 & & & & & & & & \\
\hline Date $\times$ generation & $0.001 * *$ & 1 & 10.5 & & & & & & & & \\
\hline
\end{tabular}

coef correlation coefficient

Asterisks indicate the significance level $(* * *<0.001, * * 0.001-0.01, * 0.01-0.05)$ 

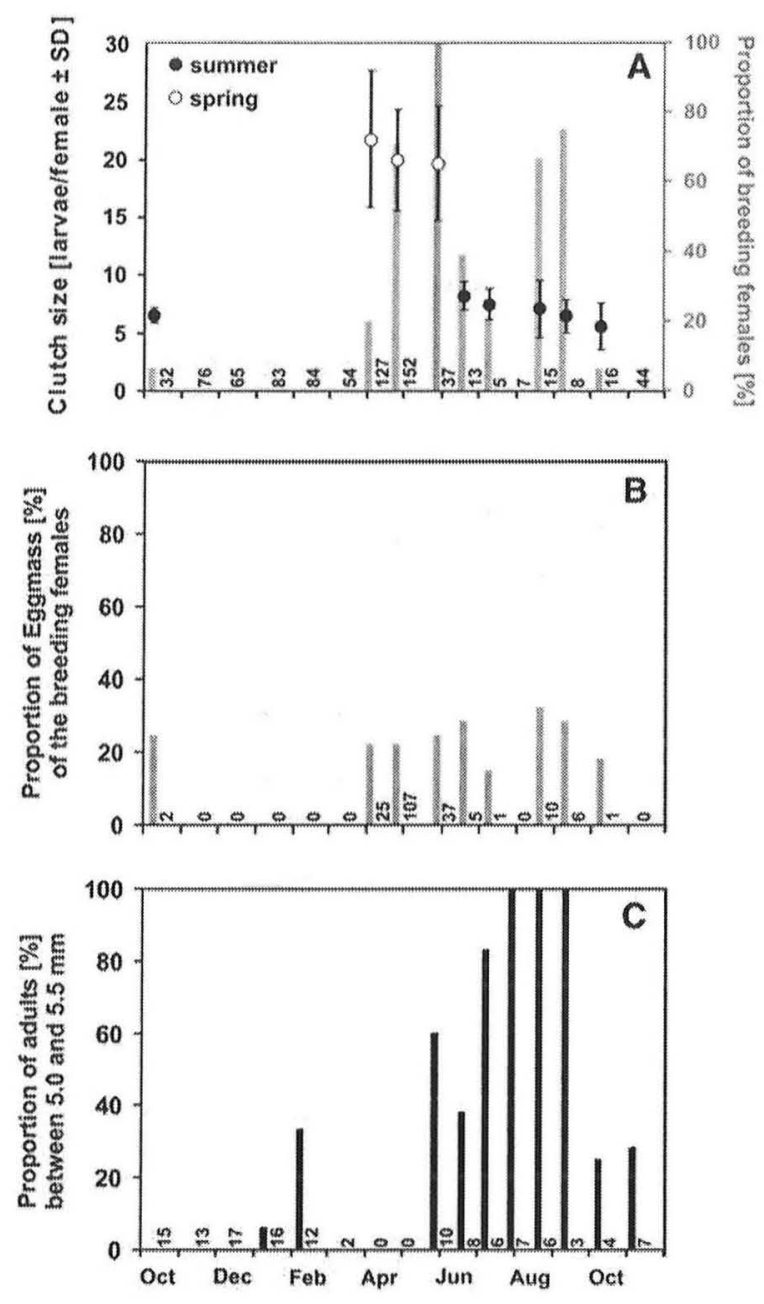

Fig. 4 A Dots Brood size as the mean $( \pm \mathrm{SD})$ of all breeding females per sampling date, separated into spring (white) and summer (black) breeding females. Bars proportion (\%) of breeding females among all females. Numbers are the sum of all females in the sample. B Proportion (\%) of egg mass on the total female biomass (mean of all gravid females). Numbers are the sum of breeding females in the sample. C Proportion (\%) of mysids between 5.0 and $5.5 \mathrm{~mm}$ classified as adult males or females. After a proportion of $50 \%$ were identified as adults, the mysids were considered as belonging to the summer generation. Numbers indicate all individuals in this length class

their life-cycle characteristics (maximal body size, stage composition, reproductive activity, clutch size, energy investment). These differences allowed us to separate the adults into two groups, which reflect the two life-cycle strategies of the species: the "winter generation", which lacks eggs from November to March and reproduces from March to May, and the "summer generation", which reproduces continuously from June to October. As clearly shown by our data, $L$. benedeni reproduces not in cohorts. Therefore it is important to note that here in this context a generation is a group of animals of unspecific age and different life stages and not a cohort.

We can summarize two important and newly described phenomena in the life cycle of $L$. benedeni. First, the adults in summer in the field are underrepresented in comparison with the predation-less mesocosm population, suggesting that they suffered huge mortality, and that only a small proportion of L. benedeni reproduced in the field. Second, the summer generation reached a smaller size at maturity compared to the winter generation and had a smaller brood size in accordance with a smaller body size, leading to a different life-cycle pattern. In the following, we explain these two different phenomena.

All considerations and conclusions on the life cycle of Limnomysis benedeni depend on the assumption that our samples are representative of the population. We think that there is good evidence for the representativeness of our samples. At our sampling site, the bank is very homogeneously covered with gravel and rocks and there is, as a matter of fact, no choice of different substrate types. Quantitative benthic invertebrate samplings at comparable sites in the littoral zone of Lake Constance indicated very similar size distributions of L. benedeni in various sampling depths $(0.5-5 \mathrm{~m}$; C. Fiek, personal communication). Despite the rareness of mature animals in summer (Fig. 4), the remaining number of adults can account for the maintenance of the population (A. J. Hanselmann, unpublished data), without a need for immigration to sustain the local population.

\section{Life-cycle characteristics}

\section{Winter generation}

In winter and early spring (November 2007-April 2008), the mysids invested their energy in increasing their body size and not in reproduction (Fig. 4B), until the end of this period in April, when the winter generation developed a large brood (Fig. 4A). The stronger length development of females in winter probably prepares the individual for a larger reproduction success. The benefit of a larger size in spring 
Table 2 Changing of adult body length in adult females and males in winter and summer, analyzed by one-way and two-way ANCOVAs

\begin{tabular}{|c|c|c|c|c|c|c|c|c|c|c|c|}
\hline \multirow[t]{3}{*}{ Season } & \multirow{2}{*}{\multicolumn{3}{|c|}{$\frac{\text { Two-way ANCOVA }}{\text { Males/females }}$}} & \multirow{2}{*}{\multicolumn{4}{|c|}{$\frac{\text { One-way ANCOVA }}{\text { Males }}$}} & \multirow{2}{*}{\multicolumn{4}{|c|}{$\frac{\text { One-way ANCOVA }}{\text { Females }}$}} \\
\hline & & & & & & & & & & & \\
\hline & $P$ value & df & $F$ & $P$ value & coef & df & $F$ & $P$ value & coef & df & $F$ \\
\hline \multicolumn{12}{|l|}{ Winter } \\
\hline Date & $<0.001 * * *$ & 1 & 572.6 & $<0.001^{* * * *}$ & 0.0079 & 1 & 65.1 & $<0.001 * * *$ & 0.0146 & 1 & 647.0 \\
\hline Sex & 0.782 & 1 & 0.1 & & & & & & & & \\
\hline Date $\times \operatorname{sex}$ & $<0.001 * * *$ & 1 & 39.7 & & & & & & & & \\
\hline \multicolumn{12}{|l|}{ Summer } \\
\hline Date & 0.161 & 1 & 2.0 & $0.006^{* *}$ & 0.0075 & 1 & 8.3 & 0.671 & -0.0008 & 1 & 0.2 \\
\hline Sex & $0.005^{* *}$ & 1 & 8.3 & & & & & & & & \\
\hline Date $\times$ sex & $0.011 *$ & 1 & 6.7 & & & & & & & & \\
\hline \multicolumn{12}{|c|}{ Summer, excluding October } \\
\hline Date & 0.404 & 1 & 0.7 & 0.606 & -0.0021 & 1 & 0.3 & 0.567 & -0.0018 & 1 & 0.3 \\
\hline Sex & 0.422 & 1 & 0.7 & & & & & & & & \\
\hline Date $\times$ sex & 0.960 & 1 & $<0.1$ & & & & & & & & \\
\hline
\end{tabular}

coef correlation coefficient

Asterisks indicate the significance level $(* * *<0.001, * * 0.001-0.01, * 0.01-0.05)$

Fig. 5 Body size

(measured from the apex to the end of the telson, see

"Methods" section) of

Limnomysis benedeni in

summer and autumn in the

mesocosm experiments

running over 19 weeks,

compared with the

population in the field (see

Fig. 2) juveniles (grey),

males (white), females

(black)

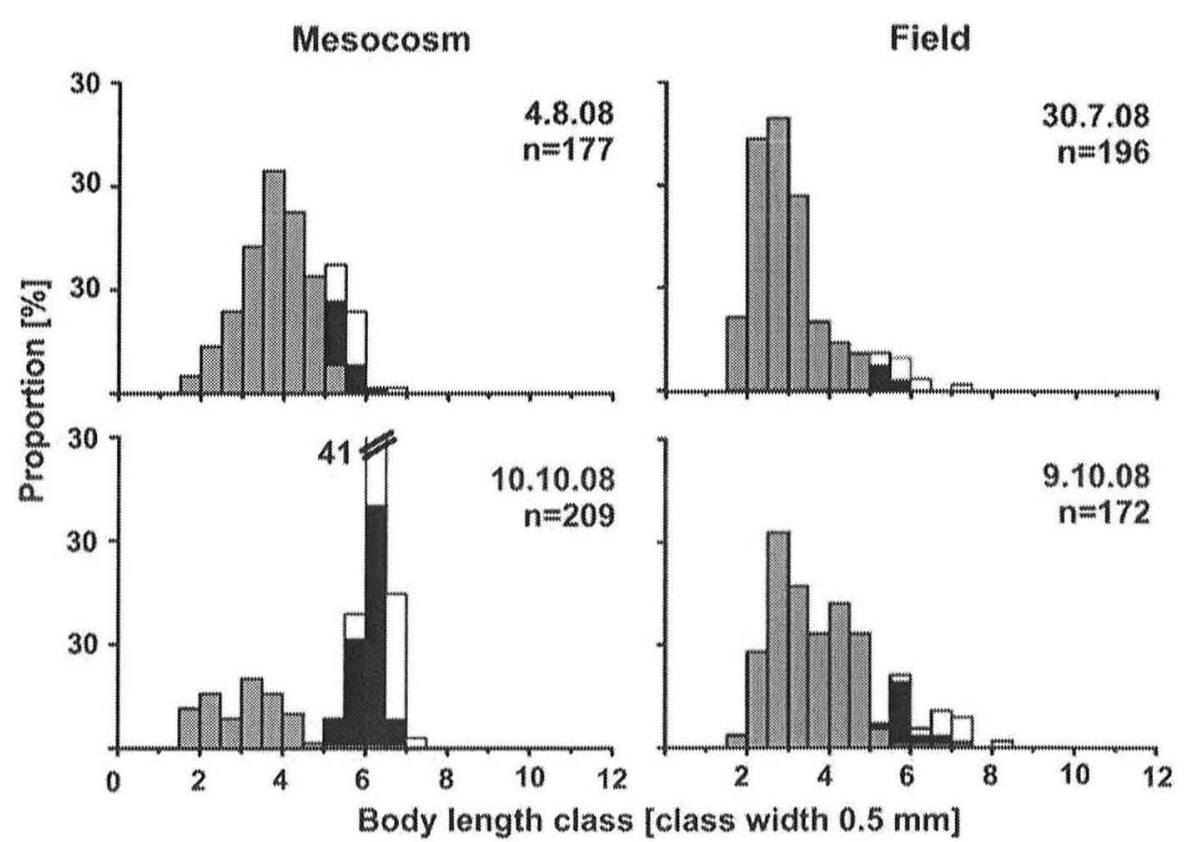

is greater for females than for males; with a larger marsupium they can produce larger broods and larger animals also accumulate larger energy reserves that can be converted to eggs (Gorokhova \& Hansson,
2000; Atkinson \& Hirst, 2007). In a previous study, Gergs et al. (2008) showed that in L. benedeni, the clutch size correlates well with the length of the female. As already described in this previous study, 


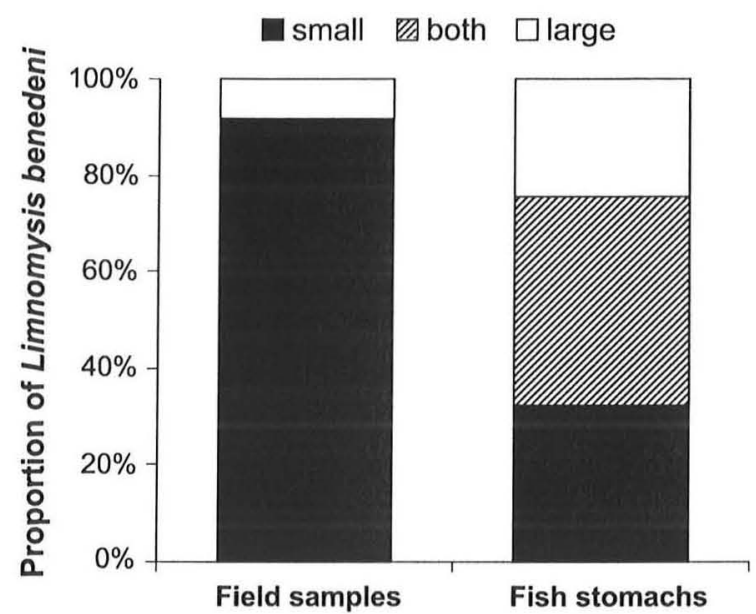

Fig. 6 Proportion of small (black, $<5.0 \mathrm{~mm}$ ) and large (white, $>5.0 \mathrm{~mm}$ ) Limnomysis benedeni consumed by young Perca fluviatilis compared with the size-distribution of L. benedeni in the field; some (shade) perch consumed both small and large L. benedeni

the sex ratio also changed in spring (Fig. 2) and the females dominated in April. Gergs et al. (2008) assumed that the females live longer and so have the chance to grow larger. By the end of May (2008), all mysids from the winter generation "disappeared" (Fig. 2). "Disappearing" means that the number of the large adults decreased markedly from April until June. We hypothesize that these adults die, either of natural senescence or predation. Migration into deeper water or the pelagic zone could also be an occurring (Boscarino et al., 2009), but in our opinion an improbable explanation, because $L$. benedeni has not been described as pelagic (Wonyárovich, 1955; Dediu, 1966). In addition, no observations of migration into deeper water were available, and we never found any large adults during the summer that had potentially drifted upwards by waves (Rinke et al., 2009).

\section{Summer generation}

The first juveniles from May (Fig. 2) reached sexual maturity in about 1 month and produced their first brood in June. The adult summer individuals showed different characteristics compared to the winter adults. Their length at maturity was smaller (Fig. 4C), a pattern also known from other species (Hilton et al., 2002). In addition, they did not reach the length of the adults in April (Fig. 3). Since the proportion of biomass that entered egg production was comparable to that of adults in April, their brood size was only one third of that of the winter generation. The females with brood invest in somatic growth about $75 \%$ of their energy budget (Fig. 4B), which is one fourth less than females without a brood. They continuously reproduced, developed several broods until October 2008, and therefore it was not possible to follow discrete peaks of the length histogram. Wittmann (1984) predicted such a pattern for mysids in the Middle European climate zone. During their reproduction period, the length distribution was clearly affected by mortality, as shown by comparing the field and mesocosm populations (Fig. 5). Despite the fact that during summer only few animals reached maturity in the field (Fig. 4), the remaining number of adults can well account for the number of juveniles. This was indicated by calculation of birth rate using temperature dependent egg development times (A. J. Hanselmann, unpublished data). With a larger sample size, the propability to find some gravid females will increase in summer.

None of the previous studies with L. benedeni described the seasonal changes in life cycle or has a comparable time resolution of the field data. Nevertheless, when we include the single samples from these previous studies (Table 3; Bacescu, 1954; Kelleher et al., 1999; Wittmann \& Ariani, 2000; Gergs et al., 2008), they follow well the patterns we describe here, but they lack a long-term dataset. The females of most mysid species grow larger than the males, but $L$. benedeni is said to show a reverse pattern (Mauchline, 1980; Wittmann, 2002). Our data support this only in part, because we could show that the length proportions changed with the season. Only during summer time the males had a larger mean body size, in winter it reversed and the females grew larger. The impression of the previous studies that the males were larger, could have arisen from their larger range of body sizes and the according larger size maximum; the standard deviations from the females body size seems to be smaller (Fig. 3). It becomes apparent, that the patterns described here, are an attribute of the whole species, and not only of the population in Lake Constance. Therefore, the adult mysids change their energy allocation, spending their available energy on growth during winter and on reproduction in summer. 
Table 3 General survey of the adult body length, the brood size, and the reproduction period of Limnomysis benedeni on several dates and from various populations and regions invaded by the species (single samples, except present study)

\begin{tabular}{|c|c|c|c|c|c|}
\hline \multirow[t]{2}{*}{ Date and location (reference) } & \multicolumn{2}{|c|}{$\begin{array}{l}\text { Body length } \text { i/ } \hat{\delta}(\mathrm{mm} \pm \mathrm{SD}) \text { or } \\
\min -\max (\mathrm{mm})\end{array}$} & \multicolumn{2}{|c|}{$\begin{array}{l}\text { Brood size (eggs/ } \\
\text { + } \pm \mathrm{SD} \text { ) or min-max } \\
\text { (eggs/o) }\end{array}$} & \multirow[t]{2}{*}{$\begin{array}{l}\text { Reproduction period } \\
\text { (months) }\end{array}$} \\
\hline & Spring & Summer & Spring & Summer & \\
\hline $\begin{array}{l}2008 \text { Lake Constance } \\
\text { (present work) }\end{array}$ & $\begin{array}{l}9.0 \pm 0.1 / 8.6 \pm 0.1 \\
11.4(\max )\end{array}$ & $\begin{array}{l}6.1 \pm 0.4 / 6.6 \pm 0.6 \\
8.5(\max )\end{array}$ & $\begin{array}{l}20.5 \pm 1.1 \\
35(\max )\end{array}$ & $\begin{array}{l}7.1 \pm 1.6 \\
10(\max )\end{array}$ & Apr-Oct \\
\hline $\begin{array}{l}2007 \text { Lake Constance } \\
\text { (Gergs et al., 2008) }\end{array}$ & $9.4 \pm 0.6 / 8.6 \pm 0.6$ & $6.7 \pm 0.8 / 6.5 \pm 0.7$ & $28.4 \pm 5.7$ & $8.7 \pm 2.9$ & Apr-Oct \\
\hline $\begin{array}{l}1998 \text { Rhine (France) } \\
\text { (Wittmann \& Ariani, 2000) }\end{array}$ & - & $6.1 \pm 0.7 / 6.8 \pm 0.4$ & - & $7.4 \pm 2.3$ & - \\
\hline $\begin{array}{l}1997 \text { Rhine (Netherlands) } \\
\text { (Kelleher et al., 1999) }\end{array}$ & \multicolumn{2}{|c|}{$6-13$} & \multicolumn{2}{|l|}{$12-40$} & Mar-Nov \\
\hline $\begin{array}{l}1954 \text { Danube (drainage basin) } \\
\text { (Bacescu, 1954) }\end{array}$ & $10-15$ (winter) & $7-10$ & $20-40$ & & Mar/Apr-Oct/Nov \\
\hline
\end{tabular}

Mortality of adults in the field

Our data show that perch prey size-selectively on large mysids, suggesting that fish predation causes high adult mortality. The stomach analyses of young perch in summer 2009 verified this hypothesis and showed that the larger $L$. benedeni undergo a size selective predation pressure. In general, young perch are dominant in the littoral of Lake Constance in summer, but not present in winter (Wang \& Eckmann, 1994; Imbrock et al., 1996) and no other fish species could be observed during our study. The perch might prefer the larger prey because they are visual hunters (Thorpe, 1977; Schleuter \& Eckmann, 2006). The gape height of young perch with about $5 \mathrm{~mm}$ (perch of $62 \mathrm{~mm}$, Guma'a, 1978) was large enough to feed on adult $L$. benedeni and perch are known to feed well on other mysids (Mauchline, 1982; Borcherding et al., 2007).

The smaller adult body size of $L$. benedeni in summer was not caused by size-selective predation as a direct mortality factor. In the mesocosm, where no fish were present, the length of the mysids remained as small as in the field with the same small size at maturity. Therefore we hypothesize that the differences to the winter generation are physiological adaptations by the mysids (Atkinson \& Hirst, 2007). Either water temperature or the photoperiod could be responsible (proximate) triggers. The ultimate factor could be predation by fish (Woodward \& Warren,
2007). An alternative hypothesis is that smaller sizes at higher temperatures result from increasing metabolism and therefore respiration losses. In other species, mainly Crustaceans, the age and/or size at maturity decreased with higher temperatures (Brown et al., 2004). In addition, it is a common phenomenon that colder environments result in larger body size (Wolfinbarger, 1999; Fockedey et al., 2005).

We conclude that predation is the reason for the dominance of the juveniles and the shifted length distribution in summer, but not for the shorter mean and maximum lengths of adults, their associated smaller clutch size or their smaller size at maturity. These are physiological adaptations, perhaps evolved to avoid negative effects of predation or as adaptions to unfavorable high temperature conditions with higher respiration loss. Also, the actual trigger for this life-cycle shift is not yet known and needs further investigations.

Acknowledgments We thank Reiner Eckmann and Monika Friedel for general help with the fish, Karen A. Brune and Lisa McMiken for editing the English language of the manuscript and the anonymous reviewers for their helpful comments. This work was supported by the DFG (German Research Foundation) within the collaborative research centre SFB 454 Littoral of Lake Constance.

\section{References}

Aßmann, C., E. Von Elert \& R. Gergs, 2009. Effects of leaf litter and its fungal colonization on the diet of Limnomysis benedeni (Crustacea: Mysida). Hydrobiologia 636: 439-447. 
Atkinson, D. \& A. G. Hirst, 2007. Life histories and body size. In Hildrew, A. G., D. G. Raffaelli \& R. Edmonds-Brown (eds), Body Size: The Structure and Function of Aquatic Ecosystems. Cambridge University Press, Cambridge: 356 pp.

Audzijonyte, A., K. J. Wittmann, I. Ovcarenko \& R. Väinölä, 2009. Invasion phylogeography of the Ponto-Caspian crustacean Limnomysis benedeni dispersing across Europe. Diversity and Distributions 15 : 346-355.

Bacescu, M., 1954. Crustacea: Mysidacea. Fauna Republicii Populare Romine 4: 1-126.

Begon, M. E., J. L. Harper \& C. R. Townsend, 1998. Ökologie Spektrum. Akademischer Verlag, Heidelberg.

Bij De Vaate, A., K. Jazdzewski, H. A. M. Ketelaars, S. Gollasch \& G. Van Der Velde, 2002. Geographical patterns in range extension of Ponto-Caspian macroinvertebrate species in Europe. Canadian Journal of Fisheries and Aquatic Sciences 59: 1159-1174.

Borcherding, J., B. Hermasch \& P. Murawski, 2007. Field observations and laboratory experiments on growth and lipid content of young-of-the-year perch. Ecology of Freshwater Fish 16: 198-209.

Boscarino, B. T., L. G. Rudstam, J. L. Eillenberger \& R. O'Gorman, 2009. Importance of light, temperature, zooplankton and fish in predicting the nighttime vertical distribution of Mysis diluviana. Aquatic Biology 5: 263-279.

Brown, J. H., J. F. Gillooly, A. P. Allen, V. M. Savage \& G. B. West, 2004. Toward a metabolic theory of ecology. Ecology 85: 1771-1789.

Chigbu, P. \& T. H. Sibley, 1998. Predation by longfin smelt (Spirinchus thaleichthys) on the mysid Neomysis mercedis in Lake Washington. Freshwater Biology 40: 295-304.

Dediu, I. I., 1966. Répartition et caractéristique écologique des Mysides des bassins des rivièrs Dniestr et Pruth. Revue roumaine de Biologie / Serie de Zoologie 11: 233-239.

Fockedey, N., J. Mees, M. Vangheluwe, T. Verslycke, C. R. Janssen \& M. Vincx, 2005. Temperature and salinity effects on post-marsupial growth of Neomysis integer (Crustacea: Mysidacea). Journal of experimental marine Biology and Ecology 326: 27-47.

Fritz, B., A. Nisch, C. Wittkugel \& M. Mörtl, 2006. First record of Limnomysis benedeni Czerniavsky in Lake Constance (Crustacea: Mysidacea). Lauterbornia 58: 157-160.

Gergs, R., A. J. Hanselmann, I. Eisele \& K. O. Rothhaupt, 2008. Autecology of Limnomysis benedeni Czerniavsky, 1882 (Crustacea: Mysida) in Lake Constance, southwestern Germany. Limnologica 38: 139-146.

Gorokhova, E. \& S. Hansson, 2000. Elemental composition of Mysis mixta (Crustacea, Mysidacea) and energy costs of reproduction and embryogenesis under laboratory conditions. Journal of experimental marine Biology and Ecology 246: 103-123.

Guma'a, S. A., 1978. The food and feeding habits of young perch, Perca fluviatilis, in Windermere. Freshwater Biology 8: 177-187.

Hilton, C., S. J. Walde \& M. L. Leonard, 2002. Intense episodic predation by shorebirds may influence life history strategy of an intertidal amphipod. Oikos 99: 368-376.
Imbrock, F., A. Appenzeller \& R. Eckmann, 1996. Diel and seasonal distribution of perch in Lake Constance: a hydroacoustic study and in situ observations. Journal of Fish Biology 49: 1-13.

Johnston, N. M., D. A. Ritz \& G. E. Fenton, 1997. Larval development in the Tasmanian mysids Anisomysis mixta australis, Tenagomysis tasmaniae and Paramesopodopsis rufa (Crustacea: Mysidacea). Marine Biology 130: 93-99.

Kelleher, B., G. Van Der Velde, K. J. Wittmann, M. A. Faasse \& A. Bij De Vaate, 1999. Current status of the freshwater Mysidae in the Netherlands: with records of Limnomysis benedeni (Czerniavsky 1882), a pontocaspian species in Dutch Rhine branches. Bulletin Zoölogisch Museum Universiteit van Amsterdam 16: 89-94.

Krebs, C. J., 2001. Ecology: The Experimental Analyses of Distribution and Abundance. Benjamin Cummings, San Francisco.

Langeland, A., J. I. Koksvik \& J. Nydal, 1991. Impact of the Introduction of Mysis relicta on the Zooplankton and Fish Populations in a Norwegian Lake. American Fisheries Society Symposium 9: 98-114.

Lasenby, D. C., T. G. Northcote \& M. Fürst, 1986. Theory, practice, and effects of Mysis relicta introductions to North American and Scandinavian Lakes. Canadian Journal of Fisheries and Aquatic Sciences 43: 1277-1284.

Lindén, E., M. Lehtiniemi \& M. Viitasalo, 2003. Predator avoidance behavior of Baltic littoral mysids Neomysis integer and Praunus flexuosus. Marine Biology 143: 845-850.

Mauchline, J., 1973. The broods of British Mysidacea (Crustacea). Journal of the Biological Association of the UK 53: $801-817$

Mauchline, J., 1980. The biology of mysids and euphausiids. Advances in Marine Biology 18: 1-681.

Mauchline, J., 1982. The predation of mysids by fish on the Rockall Trough, northeastern Atlantic ocean. Hydrobiologia 93: 85-99.

Porter, M. L., K. Meland \& W. Price, 2008. Global diversity of mysids (Crustacea-Mysida) in freshwater. Hydrobiologia 595: 213-218.

R Development Core Team, 2008. R: A Language and Environment for Statistical Computing. $\mathrm{R}$ Foundation for Statistical Computing, Vienna.

Rinke, K., A. M. R. Huber, S. Kempke, M. Eder, T. Wolf, W. N. Probst \& K. O. Rothhaupt, 2009. Lake-wide distributions of temperature, phytoplankton, zooplankton, and fish in the pelagic zone of a large lake. Limnology \& Oceanography 54: 1306-1322.

Schleuter, A., H.-P. Geissen \& K. J. Wittmann, 1998. Hemimysis anomala G. O. SARS 1907 (Crustacea: Mysidacea), an euryhaline Pontocaspian mysid in the rivers Rhine and Neckar. First report for Germany. Lauterbornia 32: 67-71.

Schleuter, D. \& R. Eckmann, 2006. Competition between perch (Perca fluviatilis) and ruffe (Gymnocephalus cern$u u s)$ : the advantage of turning night into day. Freshwater Biology 51: 287-297.

Specziár, A., 2005. First year ontogenetic diet patterns in two coexisting Sander species, $S$. lucioperca and $\mathrm{S}$. volgensis in Lake Balaton. Hydrobiologia 549: 115-130. 
Stearns, S. C., 1989. Trade-offs in life-history evolution. Functional Ecology 3: 259-268.

Thorpe, J. E., 1977. Morphology, physiology, behavior, and ecology of Perca fluviatilis $\mathrm{L}$. and $P$. flavescens Mitchill. Journal of the Fisheries Research Board of Canada 34: 1504-1514.

Wang, N. \& R. Eckmann, 1994. Distribution of perch (Perca fluviatilis $\mathrm{L}$.) during their first year of life in Lake Constance. Hydrobiologia 277: 135-143.

Wittmann, K. J., 1984. Ecophysiology of marsupial development and reproduction in Mysidacea (Crustacea). Oceanography and Marine Biology: Annual Review 22: 393-428.

Wittmann, K. J., 2002. Further expansion of Pontocaspian Mysidacea (Crustacea) into the middle and upper Danube: first records of Katamysis warpachowskyi for Hungary, Slovakia and Austria with notes on the biology and ecological risk potential. Lauterbornia 44: 49-63.

Wittmann, K. J. \& A. P. Ariani, 2000. Limnomysis benedeni: Mysidacé Ponto-Caspien nouveau pour les eaux douces de
France (Crustacea, Mysidacea). Vie et Milieu 50: $117-122$.

Wittmann, K. J. \& A. P. Ariani, 2009. Reappraisal and range extension of non-indigenous Mysidae (Crustacea, Mysida) in continental and coastal waters of eastern France. Biological Invasions 11: 401-407.

Wolfinbarger, W. C., 1999. Influences of biotic and abiotic factors on seasonal succession of zooplankton in Hugo Reservoir, Oklahoma, U.S.A. Hydrobiologia 400: 13-31.

Wonyárovich, E., 1955. Vorkommen der Limnomysis benedeni Czern. im ungarischen Donauabschnitt. Acta zoologica Academiae Scientiarum Hungaricae 1: 177-185.

Woodward, G. \& P. Warren, 2007. Body size and predatory interactions in freshwater: scaling from individuals to communities. In Hildrew, A. G., D. G. Raffaelli \& R. Edmonds-Brown (eds), Body Size: The Structure and Function of Aquatic Ecosystems. Cambridge University Press, Cambridge: $356 \mathrm{pp}$. 